\title{
Biofilm production and other virulence factors in Streptococcus spp. isolated from clinical cases of bovine mastitis in Poland
}

\author{
Edyta Kaczorek *iD, Joanna Małaczewska, Roman Wójcik and Andrzej Krzysztof Siwicki
}

\begin{abstract}
Background: Mastitis is a common disease in dairy cattle throughout the world and causes considerable economic losses each year. An important aetiological agent of this disease is bacteria of the genus Streptococcus; hence, exploring the mechanisms of virulence in these bacteria is an extremely important step for the development of effective prevention programmes. The purpose of our study was to determine the ability to produce biofilm and the occurrence of selected invasiveness factors among bacteria of the genus Streptococcus isolated from cattle with the clinical form of mastitis in northeastern Poland.

Results: Most of the isolates analysed demonstrated an ability to produce biofilm (over 70\%). Virulence genes were searched for in the three most common streptococci in our experiment: S. agalactiae, S. uberis and S. dysgalactiae. For S. agalactiae, only four genes were confirmed: rib (33\%), cylE (78\%), bca (37\%), and cfb (100\%). The genes pavA, scpB, bac and Imb were not present in any of the tested strains. The dominant serotypes of the species were la $(n=8)$ and II $(n=8)$, in addition to some strains that were not classified in any of the groups $(n=6)$. Out of the eight selected genes for S. uberis (sua, pauA/skc, gapC, cfu, Ibp, hasA, hasB, hasC), only one was not found (Ibp). Finally, two genes were chosen for S. dysgalactiae (eno and napr), and their presence was confirmed in $76 \%$ and $86 \%$ of the strains, respectively.
\end{abstract}

Conclusions: The experiment showed that strains of Streptococcus spp. isolated from dairy cattle with clinical cases of mastitis in the northeastern part of Poland possess several invasiveness factors that can substantially affect the course of the disease, and this should be considered when developing targeted prevention programmes.

Keywords: Streptococcus, Mastitis, Biofilm, Virulence genes

\section{Background}

Mastitis in dairy cattle is a globally widespread disease that is responsible for large economic losses each year due to lower milk yield and reduced milk quality [1]. One of the aetiological factors mentioned most often are bacteria of the genus Streptococcus, where pathogens classified as both contagious (e.g., Streptococcus agalactiae) and environmental (e.g., Streptococcus uberis) can be distinguished [2-4].

It is common knowledge that antibiotics are among the major tools in combating this disease [1]. However, to avoid development and spread of antibiotic resistance, the use of the antibiotics in the treatment of mastitis should be limited to situations where clinical and bacteriological

\footnotetext{
* Correspondence: edyta.kaczorek@uwm.edu.pl

Department of Microbiology and Clinical Immunology, Faculty of Veterinary

Medicine, University of Warmia and Mazury in Olsztyn, Oczapowskiego 13, 10-719 Olsztyn, Poland
}

findings justify their use. Sometimes, in spite of using an active substance that shows efficacy under in vitro conditions, antibiotic therapy is not effective. These situations are associated with the presence of various host and bacterial factors, including the ability of bacteria to produce biofilm [5, 6]. 'Biofilm' is defined as a matrix-enclosed microbial accretions which can adhere both to biological or non-biological surfaces. By producing various types of substances, the formation of biofilm is a significant factor in the pathogenesis of numerous diseases, both in humans and in animals [7-9].

By forming such a structure, bacteria are more likely to survive in an environment that is hostile to them, and after invading an organism, they can be better protected against the action of the host immune system while becoming less sensitive to the activity of antibiotics or disinfectants [7, 10]. In addition to the ability to produce biofilm, Streptococcus 
spp. possess other invasiveness factors, for example those that provide protection against the host immune system (e.g., plasminogen activator, lactoferrin binding protein, or CAMP factor) $[11,12]$. For years, the presence of specific virulence factors in pathogens has drawn the attention of research teams throughout the world because such research increases our understanding of the mechanisms responsible for inducing an illness and can therefore contribute to the development of optimal prevention programmes.

To date, several studies have evaluated the ability of Streptococcus spp. to produce biofilms as well as the presence of virulence factors in bacteria isolated from dairy cattle suffering from mastitis in different countries; however, we are the first to examine such phenomena in our region $[8,11,13]$. Hence, the purpose of our study was to identify the ability of bacteria to make biofilm and to detect the presence of selected virulence factors in bacteria of the genus Streptococcus isolated from cattle with the clinical form of udder inflammation in northeastern Poland.

\section{Methods \\ Sample collection}

A total of 135 previously described streptococcal isolates were used in this study [14]. All samples were collected from 65 different farms in north-eastern Poland from 2013 to 2015. To avoid testing of epidemiologically related isolates, only 1 isolate from one species per dairy farm was included. Prior to milk sampling, all animals were tested using the California mastitis test. Only milk from quarters presenting symptoms of infection was collected (i.e., slight thickening of the mixture; trace reaction seems to disappear with continued rotation of the paddle, CMT $\geq 4$ ). After sampling, milk was kept in a container that was maintained a constant temperature of 6 to $8{ }^{\circ} \mathrm{C}$ and was delivered to the laboratory within $2 \mathrm{~h}$.

\section{Bacteriological identification}

Milk samples were transferred with a calibrated loop $(0.01 \mathrm{ml})$ onto Columbia agar (Oxoid, Great Britain) and Edwards medium (Oxoid, Great Britain), both supplemented with $5 \%$ defibrinated sheep blood. The plates were incubated at $37{ }^{\circ} \mathrm{C}$ for $48 \pm 2 \mathrm{~h}$ under aerobic conditions. The grown cultures were examined microscopically after Gram staining, and the phenotypic traits were analysed (i.e., type of haemolysis, esculin hydrolysis, catalase production, CAMP reaction). For further analysis, only $\mathrm{G}+$, catalase-negative cocci were selected. The final identification was performed using the commercial latex agglutination test Streptococcal Grouping Kit (Oxoid, Great Britain), API strep (bioMérieux, France) and PCR. All strains used in this study are summarized in Table 1.
Table 1 Strains used in this study

\begin{tabular}{ll}
\hline Species & $n$ \\
\hline S.uberis & 53 \\
S. dysgalactiae & 41 \\
S. agalactiae & 27 \\
Other Streptococci & 14 \\
\hline
\end{tabular}

\section{DNA isolation}

Bacterial DNA was extracted using the ExtractMe DNA bacteria kit (Blirt, Gdańsk, Poland) according to the manufacturer's protocols. Eluted DNA concentrations were measured using the BioSpectrometer ${ }^{\circledR}$ (Eppendorf, Hamburg, Germany) and stored at $-20{ }^{\circ} \mathrm{C}$ for further analysis.

\section{Detection of virulence genes of S. agalactiae, S. uberis and S. dysgalactiae}

Virulence genes for $S$. uberis (sua, pauA/skc, gap $C$, has $C$, $l b p$, cfu, has B, has A), S. agalactiae (pava, scpB, rib, bac, $c y l E, b c a, c f b, l m b$ ) and $S$. dysgalactiae (eno, napr) were amplified using PCR. The confirmation of $S$. agalactiae, $S$. uberis and $S$. dysgalactiae, has been previously described [14]. Primer sequences, product sizes and annealing temperatures are summarized in Table 2. All primers were synthesized by Genomed S.A. (Warsaw, Poland). Amplification reactions were carried out with HotStarTaq Plus Master Mix Kit (Qiagen, Hilden, Germany) in a nexus gradient thermocycler (Eppendorf, Hamburg, Germany) using the same PCR protocol as described before [14]. All PCR reactions were carried out with positive and negative controls. Some PCR products of interest were randomly chosen and purified using a CleanUp kit (A\&A Biotechnology, Gdynia, Poland) for sequencing (Genomed, Warsaw, Poland) to confirm the specificity of the obtained amplicons.

\section{Biofilm assay}

The experiment was performed using polystyrene microtiter plates with flat bottoms based on the techniques described by Ebrahimi et al. [13]. All isolates were grown in tryptic soy broth (TSB, Oxoid, Great Britain) at $37{ }^{\circ} \mathrm{C}$ for $16 \mathrm{~h}$. The bacterial cells were centrifuged at $6000 \mathrm{~g}$ for $10 \mathrm{~min}$. Supernatants were removed and the cell pellets were resuspended in $5 \mathrm{~mL}$ of fresh medium (TSB) to achieve an absorbance of 1.00 at $595 \mathrm{~nm}$. The optical density (ODs) of the bacterial suspensions were measured using the BioSpectrometer ${ }^{\oplus}$ (Eppendorf, Hamburg, Germany). The suspensions were then diluted 1:40 in fresh TSB, and $200 \mu \mathrm{l}$ of the diluted cell suspension was added to each well of the microtiter plate ( 8 wells in a single row for one strain). Plates were incubated at $37{ }^{\circ} \mathrm{C}$ for $24 \mathrm{~h}$. The plates were then washed three times with sterile phosphatebuffered saline (PBS). The inverted plates were dried at ambient temperature for $1 \mathrm{~h}$. Next, the plates were stained with $200 \mu \mathrm{l}$ of $0.2 \%$ aqueous crystal violet solution for 
Table 2 Primer sets used for the detection of virulence genes in Streptococcus spp.

\begin{tabular}{|c|c|c|c|c|c|c|}
\hline Primer function & Putative function & Target gene & Primer sequence $\left(5^{\prime}-3^{\prime}\right)$ & $\begin{array}{l}\text { Amplicon } \\
\text { size (bp) }\end{array}$ & $\begin{array}{l}\text { Annealing } \\
\text { temperature }\left({ }^{\circ} \mathrm{C}\right)\end{array}$ & Reference \\
\hline \multicolumn{7}{|l|}{ Virulence genes } \\
\hline \multicolumn{7}{|l|}{ Suberis } \\
\hline Adhesion molecue- & $\begin{array}{l}\text { Adherence and invasion of } \\
\text { mammary epithelial cells }\end{array}$ & sua & $\begin{array}{l}\text { TCAACTTGACGAATCGCTTG } \\
\text { TCAGCCATTGTTTCTGCTTG }\end{array}$ & 480 & 47 & {$[20]$} \\
\hline Plasminogen activator & colonization & pauA/skc & $\begin{array}{l}\text { CGGGTTGAAGAACCTATCACTC } \\
\text { TGGAAGTTGACCAAGAGAATTG }\end{array}$ & 255 & 50 & {$[20]$} \\
\hline $\begin{array}{l}\text { Surfacedehydrogenase } \\
\text { protein }\end{array}$ & colonization & gapC & $\begin{array}{l}\text { GCTCCTGGTGGAGATGATGT } \\
\text { GTCACCAGTGTAAGCGTGGA }\end{array}$ & 200 & 51 & [11] \\
\hline CAMP factor & $\begin{array}{l}\text { Forms pores in host-cell } \\
\text { membran }\end{array}$ & $c f u$ & $\begin{array}{l}\text { TATCCCGATTTGCAGCCTAC } \\
\text { CCTGGTCAACTTGTGCAACTG }\end{array}$ & 205 & 50 & {$[11]$} \\
\hline $\begin{array}{l}\text { Lactoferrin binding } \\
\text { protein }\end{array}$ & Binding Lactoferrin & Ibp & $\begin{array}{l}\text { CGACCCTTCAGATTGGATTC } \\
\text { TAGCAGCATCACGTTCTTCG }\end{array}$ & 698 & 50 & {$[11]$} \\
\hline \multirow[t]{3}{*}{ Hyaluronic acid capsule } & Resistance to phagocytosis & has $A$ & $\begin{array}{l}\text { GAAAGGTCTGATGCTGATG } \\
\text { TCATCCCCTATGCTTACAG }\end{array}$ & 319 & 44 & [33] \\
\hline & & has $B$ & $\begin{array}{l}\text { TCTAGACGCCGATCAAGC } \\
\text { TGAATTCCTATGCGTCGATC }\end{array}$ & 532 & 47 & [33] \\
\hline & & hasC & $\begin{array}{l}\text { TGCTTGGTGACGATTTGATG } \\
\text { GTCCAATGATAGCAAGGTCAC }\end{array}$ & 225 & 47 & [33] \\
\hline \multicolumn{7}{|l|}{ S.agalactiae } \\
\hline $\begin{array}{l}\text { Adherence and virulence } \\
\text { protein A }\end{array}$ & $\begin{array}{l}\text { Binding to immobilized } \\
\text { fibronectin }\end{array}$ & pava & $\begin{array}{l}\text { TTCCCATGATTTCAACAACAAG } \\
\text { AACCTTTTGACCATGAATTGGTA }\end{array}$ & 495 & 47 & {$[20]$} \\
\hline $\begin{array}{l}\text { Streptococcal C5a } \\
\text { peptidase- adhesion }\end{array}$ & $\begin{array}{l}\text { Prevents neutropil, promotes } \\
\text { adherence }\end{array}$ & $s c p B$ & $\begin{array}{l}\text { AGTTGCTTCTTACAGCCCAGA } \\
\text { GGCGCAGACATACTAGTTCCA }\end{array}$ & 567 & 51 & {$[20]$} \\
\hline Surface protein Rib- & Resistance to proteases & $r i b$ & $\begin{array}{l}\text { CAGGAAGTGCTGTTACGTTAAAC } \\
\text { CGTCCCATITAGGGTCTTCC }\end{array}$ & 369 & 51 & [34] \\
\hline $\mathrm{C}$ beta protein & $\begin{array}{l}\text { Binds to the immuno-globulin } \\
\text { A }\end{array}$ & bac & $\begin{array}{l}\text { CTATTTTTGATATTGACAATGCAA } \\
\text { GTCGTTACTTCCTTGAGATGTAAC }\end{array}$ & 592 & 46 & {$[35]$} \\
\hline B-haemolisin & Promotes invasion of host cells & CylE & $\begin{array}{l}\text { TGACATTTACAAGTGACGAAG } \\
\text { TTGCCAGGAGGAGAATAGGA }\end{array}$ & 248 & 47 & {$[36]$} \\
\hline C alfa protein & Adherence to epithelial cells & $b c a$ & $\begin{array}{l}\text { TAACAGTTATGATACTTCACAGAC } \\
\text { ACGACTITCTTCCGTCCACTTAGG }\end{array}$ & 535 & 49 & {$[37]$} \\
\hline CAMP factor & $\begin{array}{l}\text { Forms pores in host-cell } \\
\text { membran }\end{array}$ & $c f b$ & $\begin{array}{l}\text { ATGGGATTTGGGATAACTAAGCTAG } \\
\text { AGCGTGTATTCCAGATTTCCTTAT }\end{array}$ & 193 & 50 & {$[38]$} \\
\hline $\begin{array}{l}\text { Lamining-binding } \\
\text { protein }\end{array}$ & $\begin{array}{l}\text { Promote adherence to host } \\
\text { laminin }\end{array}$ & $\operatorname{lmb}$ & $\begin{array}{l}\text { AGTCAGCAAACCCCAAACAG } \\
\text { GCTTCCTCACCAGCTAAAACG }\end{array}$ & 397 & 50 & [39] \\
\hline \multicolumn{7}{|l|}{ S.dysgalactiae } \\
\hline a-enolase & Plasminogen binding & eno & $\begin{array}{l}\text { ATGTCAATTATTACTGATGT } \\
\text { CTATIIIITAAGTTATAGA }\end{array}$ & 1308 & 36 & {$[17]$} \\
\hline $\begin{array}{l}\text { Nephritis-associated } \\
\text { plasminogen-binding } \\
\text { receptor }\end{array}$ & Plasminogen binding & napr & $\begin{array}{l}\text { GTTAAAGTTGGTATTAACGGT } \\
\text { TTGAGCAGTGTAAGACATTTC }\end{array}$ & 963 & 45 & {$[17]$} \\
\hline
\end{tabular}

$15 \mathrm{~min}$. The plates were then washed three times with sterile PBS to remove excess dye. Crystal violet bound to the biofilms was extracted with $200 \mu \mathrm{l}$ of an 80:20 ( $\mathrm{v} / \mathrm{v}) \mathrm{mix}-$ ture of ethyl alcohol and acetone and the absorbance was measured at $595 \mathrm{~nm}$ using an ELISA plate reader (Sunrise absorbance reader, Tecan, Austria). Non-inoculated TSB wells stained with crystal violet were used as negative controls. All assays were performed in triplicate with 8 replicates for each strain. Interpretation of biofilm production was according to the criteria described by [15]. The mean optical density (OD) of the negative control +3 standard deviations of negative control was considered the cut-off $(\mathrm{ODc}=0,2)$, and the biofilm producers were therefore categorized as follows:

- not a biofilm producer: OD $\leq$ ODc, (all strains which OD values were below 0,2)

- weak biofilm producer ODc: $<$ OD $\leq 2 \times$ ODc, (all strains which OD values were above 0,2 and below 0,4) 
- moderate biofilm producer: $2 \times \mathrm{ODc}<\mathrm{OD} \leq 4 \times \mathrm{ODc}$ (all strains which OD values were above 0,4 and below 0,8 )

- strong biofilm producer: OD $>4 \times$ ODc. (all strains which OD values were above 0,8 ).

\section{Molecular serotyping of Streptococcus agalactiae}

The assay was performed by multiplex PCR using a protocol previously described by Poyart el al. [16]. The protocol is based on two multiplex PCRs, one containing the primer pairs specific for serotypes Ia, Ib, II, III, and IV and the other containing primer pairs specific for serotypes V, VI, VII, VIII. Serotype IX was not investigated using this method. Non-typeable isolates were designated 'NT'. To confirm the specificity of the obtained amplicons, some PCR products of interest were randomly chosen and purified using a CleanUp kit (A\&A Biotechnology, Gdynia, Poland) for sequencing (Genomed, Warsaw, Poland).

\section{Results}

\section{Biofilm production}

Most of the analysed strains, which were classified into four groups (S. agalactiae, S. uberis, S. dysgalactiae and other streptococci), showed the ability to produce biofilm (over $70 \%)$. The occurrence of strains characterized as strong biofilm producers was noted in only two species (S. uberis and S. agalactiae; $6 \%$ and $7.5 \%$, respectively) [Table 3].

\section{Detection of virulence genes}

Virulence genes were searched for in the three species of streptococci most frequently appearing in our study, i.e., $S$. agalactiae, S. uberis and S. dysgalactiae. For the remaining category of other streptococci $(n=14)$, invasiveness genes were not determined due to species diversity in this group (four different species).

Regarding S. agalactiae $(n=27)$, the eight most common virulence genes in this species were selected for analysis. Among the analysed isolates, the presence of only four genes was confirmed: $r i b$ (33\%), cylE (78\%), bca (37\%), cfb (100\%). The genes $p a v A, s c p B, b a c$ and $1 m b$ did not occur in any of the tested strains [Table 4].

As for the strains of $S$. uberis $(n=53)$, eight genes connected with virulence were selected for analysis. Only one gene, $l b p$, was not found in the isolates of this species.
The other genes were quite abundant at70\%. One exception was a gene of the has operon, has $A$, which was identified in only $17 \%$ of the analysed strains [Table 4].

The last group submitted to analysis consisted of isolates of $S$. dysgalactiae $(n=41)$. In this group, only two genes, eno and napr, were selected for the tests, mainly because there is very little knowledge about the mechanisms of invasiveness in this species [17] Regarding our isolates, the presence of these two genes was confirmed in $76 \%$ and $86 \%$ of strains, respectively [Table 4].

\section{Molecular serotyping of Streptococcus agalactiae and associated virulence genes}

The presence of serotypes Ia, Ib, II, III, IV and V was confirmed among the analysed strains, and the most numerous group consisted of serotypes Ia and II $(n=8)$. In our experiment, there were 6 strains which could not be classified into any of the analysed serotypes (NT). In addition, an analysis was performed regarding the presence of virulence genes in the individual serotypes. In the case of serotype Ia, only one profile was observed: $r i b, c y l E, c f b$. The profile $c y l E, b c a, c f b$ dominated in the second most numerous group, i.e., serotype II. In the NT strains, there was only one gene: $c f b$ [Table 5].

\section{Discussion}

The presence or absence of virulence factors in pathogenic aetiological agent of a disease is an important variable that decides the course of the illness itself. The enzymes and toxins produced by bacteria or the ability of bacteria to produce biofilm help microorganisms survive in infected tissues either through direct impact on host stromal cells or by affecting host defence mechanisms [18]. In our experiment, most of the analysed isolates of Streptococcus spp. demonstrated an ability to produce biofilm (over 70\%), many of which represented strains forming a weak structure. Such high abundance in this group can be explained by the fact that determinations in strains were made after a 24-h incubation period. Moliva et al. [19] recently showed that strains of S. uberis begin to form biofilm structure as early as after $2 \mathrm{~h}$ of incubation, but mature biofilm is not formed until after $48 \mathrm{~h}$. It is possible that the relatively longer incubation of isolates in our study influenced the results. Nevertheless, we are convinced that the high occurrence of Streptococcus spp.

Table 3 Biofilm production capability and formation intensity

\begin{tabular}{lllll}
\hline Species & No biofilm producers & Weak biofilm producers & Moderate biofilm produres & Strong biofilm producers \\
\hline S.uberis & $12(23 \%)$ & $33(62 \%)$ & $5(9 \%)$ & $3(6 \%)$ \\
S.dysgalactiae & $5(13 \%)$ & $26(63 \%)$ & $10(24 \%)$ & $0(0 \%)$ \\
S.agalactiae & $2(7,5 \%)$ & $20(74 \%)$ & $3(11 \%)$ & $2(7,5 \%)$ \\
other & $3(21 \%)$ & $10(72 \%)$ & $1(7 \%)$ & $0(0 \%)$
\end{tabular}

S. agalactiae $(n=27)$, S. uberis $(n=53)$, S. dysgalactiae $(n=41)$ and other streptococci $(n=14)$ 
Table 4 Frequency of occurrence [no. (\%)] of the chosen virulence genes

\begin{tabular}{|c|c|c|c|c|c|c|c|c|}
\hline \multicolumn{9}{|c|}{ S.agalactiae } \\
\hline & pava & $\operatorname{scp} B$ & rib & bac & cyle & bca & $c f b$ & $\operatorname{lmb}$ \\
\hline$n$ & 0 & 0 & 9 & 0 & 21 & 10 & 27 & 0 \\
\hline$\%$ & 0 & 0 & 33 & 0 & 78 & 37 & 100 & 0 \\
\hline \multicolumn{9}{|c|}{ S. uberis } \\
\hline & sua & pauAvske & gapC & $c f u$ & $1 b p$ & has A & has $B$ & hasC \\
\hline$n$ & 51 & 50 & 52 & 10 & 0 & 9 & 42 & 44 \\
\hline$\%$ & 96 & 94 & 98 & 19 & 0 & 17 & 79 & 83 \\
\hline \multicolumn{9}{|c|}{ S.dysgalactiae } \\
\hline & eno & naprl & & & & & & \\
\hline$n$ & 31 & 34 & & & & & & \\
\hline$\%$ & 76 & 83 & & & & & & \\
\hline
\end{tabular}

Streptococcus uberis $(n=53)$, Streptococcus agalactiae $(n=27)$, Streptococcus dysgalactiae $(n=41)$, and other Streptococcus species $(n=14)$

strains able to produce biofilm in the geographical area we investigated presents a serious challenge for both dairy farmers and veterinary doctors. As mentioned earlier, the production of this specific structure by bacteria can have a considerable impact upon treatment efficiency. From a clinical point of view, there is a significant relationship between the ability to create bacterial biofilm and antibiotic treatment [7]. Bacteria that form a 'biological membrane' can be characterized by up to 1000-fold lower sensitivity to the effects of some active substances compared to strains growing in planktonic form. In addition, some antibiotics, for example tetracyclines or erythromycin, can stimulate the formation of biofilm. This was observed in the case of Staphylococcus epidermidis, where following the administration of these antibiotics there was an observed increase in the expression of the gene responsible for the formation of biofilm (ica) [7]. In our earlier studies conducted on the same strains [14], we found a high level of resistance of these pathogens to tetracycline. This observation may indicate that the said active substance is overused in the analysed area, and simultaneously may

Table 5 Results of molecular serotyping of S. agalactiae strains ( $n=27$ ) (including virulence profiles)

\begin{tabular}{llllll}
\hline Serotype & $n$ & Profile & & \\
\cline { 3 - 6 } & & $r i b, c y \mid E, c f b$, & $c y \mid E, b c a, c f b$ & $c y \mid E, c f b$ & $c f b$ \\
\hline la & 8 & 8 & 0 & 0 & 0 \\
Ib & 2 & 2 & 0 & 0 & 0 \\
II & 8 & 0 & 7 & 1 & 0 \\
III & 1 & 0 & 1 & 0 & 0 \\
IV & 1 & 0 & 0 & 1 & 0 \\
V & 1 & 0 & 1 & 0 & 0 \\
NT & 6 & 0 & 1 & 0 & 5 \\
\hline
\end{tabular}

explain the presence of such a high number of strains able to produce biofilm. However, we have not observed any correlation between biofilm formation ability and other virulence factors occurrence. This may provide that biofilm formation is not essential in the pathogenesis of mastitis in dairy cattle in the analysed area for now.

Next, we analysed bacteria searching for the presence of the selected virulence genes. Eight genes were selected or $S$. agalactiae, of which four ( $r i b, c y l E, b c a, c f b)$ were determined to be present in the analysed strains. These results were unsurprising because their presence had been previously confirmed in bovine strains in countries such as Brazil, India or Egypt, and the frequency of occurrence of these genes is local in character [12, 19-21]. The situation differs with respect to the genes $s c p B, \operatorname{lmb}$, $p a v A$ and $b a c$, whose presence was not detected in the strains we analysed. On the one hand, these genes are mainly associated with human strains, and therefore their absence is not puzzling $[12,20]$. On the other hand, the genes $s c p B$, pavA or $\operatorname{lmb}$ have been detected in isolates of $S$. agalactiae derived from cattle with mastitis in Asia and Africa [20-22]. Thus, our findings indicate that these four genes probably do not play important roles in the pathogenesis of udder inflammation in dairy cattle in the region, which may be connected with the different conditions and management practices for dairy cattle in Europe.

In the case of $S$. agalactiae, we performed additional molecular serotyping of the isolated strains. Such investigations are extremely important considering both epidemiology and prophylaxis, as they may aid the development of multivalent vaccines containing capsular polysaccharides [23]. Our isolates belonged to serotypes from Ia to $\mathrm{V}$. The occurrence of these serotypes need not be surprising, as they were isolated previously in the United States and Europe; however, the dominance of serotype Ia in our study is quite puzzling because according to Delannoy et al. [24], this serotype is mostly present in humans. Serotype III is usually dominant in cattle but in our experiment it was confirmed in only one case. Nevertheless, the presence of serotype Ia in cattle has also been confirmed in the eastern part of China, Germany and the USA $[23,25,26]$. These observations collectively seem to support the claim that the presence of specific serotypes may be a local characteristic due to several factors (e.g., breed of cattle, geographic location, farm management), which highlights the importance of serotyping studies for selecting appropriate prevention measures [23, 25, 26]. In our study, we also found strains not classified to any serotype. This was not surprising because such strains are quite frequently observed among $S$. agalactiae isolated from cattle [25]. Nonetheless, we did not determine serotype IX in our experiment, and consequently, the number of strains in the NT group may be unduly high. In addition, we analysed of the presence of virulence genes in individual serotypes of $S$. agalactiae. Interestingly, despite the frequent presence of 
serotype IA that is typical of human diseases, we did not detect in this serotype genes characteristic for human strains of $S$. agalactiae (scpB, lmb, pavA or bac). In the two most often isolated serotypes IA and II, the dominance of two virulence profiles was observed: $r i b, c y l E$, $c f b$, and $b c a, c y l E$, $c f b$, respectively. These serotypes differed from each other by the presence of two genes: $r i b$ and $b c a$. These genes belong to the same family, the alpha-like protein (Alp) family, and play important roles in the pathogenesis of illnesses caused by these bacteria, and they are also acknowledged as vaccine candidates [23]. Our results suggest that vaccines should contain at least two genes from this family because their presence may be correlated with the dominant serotype. However, there is a need to kept in mind that in the case of these bacteria there is a possibility of horizontal or lateral gene transfer. According to the Richards et al. [27] S.agalactiae can transfer genetic material both to their own species and other mastitis pathogens such as S.uberis or S.dysgalactiae, which is one of the mechanisms of these bacteria for adaptation to the bovine environment. However, our study was performed on a relatively small number of strains isolated from just one species, and further studies in this direction are necessary.

Eight genes (sua, pauA/skc, gapC, cfu, lbp, hasA, hasB, hasC) were selected for $S$. uberis, of which the following were most frequent: gapC (98\%), sua (96\%) and pauA/ $s k c(94 \%)$. The presence of the gene $l b p$ was not detected among the analysed strains. The three genes dominant in our study were previously confirmed at similar levels in Argentina, India, Great Britain, New Zealand and the USA [11, 28-31]. These genes are considered as good targets for vaccine development due to frequent occurrence and their highly conserved nature at the nucleotide and amino acid levels [11, 28, 32]. In our experiment, we also chose to analyse genes of the has operon (has $A B C$ ), which is responsible for capsule production. The key role in this process is played by the gene has $A$, which was rather rare (17\%) among the analysed strains. This finding suggests that in the region investigated, the ability of $S$. uberis to produce capsules does not play a key role in mastitis [11].

In $S$. dysgalactiae, we focused on two genes that encode proteins responsible for binding host plasminogen (naprl and eno). Both occurred quite frequently among the analysed strains (approximately 80\%). Similar results for these two genes have been observed among $S$. dysgalactiae strains isolated from fish and pigs in Asian countries [17].

\section{Conclusions}

In summary, the experiment reported above showed that strains of Streptococcus spp. in northeastern Poland possess several invasiveness factors, which can considerably influence the course of disease and treatment. The data obtained during our study constitute a preliminary step towards further research targeting a better understanding of the dominant virulence mechanisms among these bacteria, and they may aid the development of target prevention programmes for this region of the country.

\section{Acknowledgements}

We would like to thank Wojciech Rękawek for collecting samples for this research.

\section{Funding}

Publication was supported by KNOW (Leading National Research Centre) Scientific Consortium "Healthy Animal-Safe Food," decision of the Ministry of Science and Higher Education No. 05-1/KNOW2/2015.

\section{Availability of data and materials}

All the raw data analysed in this paper are available from the corresponding author on reasonable request.

\section{Authors' contributions}

EK performed all PCR testing, bacterial identification and biofilm assay. JM was responsible for interpretation of data and study design. RW revised the manuscript, AKS contributed to the study design, conception, and interpretation of data. All authors read, revised, and approved the final manuscript.

Ethics approval and consent to participate

Not applicable.

\section{Consent for publication}

Not applicable.

\section{Competing interests}

The authors declare that they have no competing interests.

\section{Publisher's Note}

Springer Nature remains neutral with regard to jurisdictional claims in published maps and institutional affiliations.

Received: 4 August 2017 Accepted: 18 December 2017

Published online: 28 December 2017

\section{References}

1. Thomas V, Jong A, Moyaert H, Simjee S, Garch FE, Morrissey I, et al. Antimicrobial susceptibility monitoring of mastitis pathogens isolated from acute cases of clinical mastitis in dairy cows across Europe: VetPath result. Int J Antimicrob Agents. 2015;46:13-20.

2. Neiwert O, Holst O, Duda KA. Structural investigation of rhamnose-rich polysaccharides from Streptococcus dysgalactiae bovine mastitis isolate. Carbohydr Res. 2014;389:192-5.

3. Bradley AJ. Bovine Mastitis: an evolving disease. Vet J. 2002;164:116-28.

4. Pieterse R, Todorov SD. Bacteriocins- exploring alternatives to antibiotics in mastitis teratment. Braz J Microbiol. 2010;41:542-62.

5. Preez JH. Bovine mastitis therapy and why it fails. J S Afr Vet Assoc. 2000;71:201-8.

6. Sordillo LM. Factors affecting mammary gland immunity and mastitis susceptibility. Livest Prod Sci. 2005;98:89-99.

7. Melchior MB, Vaarkamp H, Fink-Gremmels J. Biofilms: a role in recurrent mastitis infections? Vet J. 2006;171:398-407.

8. Boonyayatra S, Pata P, Nakharuthai P, Chaisri W. Antimicrobial resistance of biofilm-forming Streptococcus agalactiae isolated from bovine mastitis. J Vet Sci Technol. 2016; https://doi.org/10.4172/2157-7579.1000374.

9. Costerton JW, Stoodley P. Bacterial biofilms: from the natural environment to infectious diseases. Nat Rev Microbiol. 2004;2:95-108.

10. Felipe V, Morgante CA, Somale PS, Varroni F, Zingaretti ML, Bachetti RA, et al. Evaluation of the biofilm forming ability and its associated genes in Staphylococcus species isolates from bovine mastitis in Argentinean dairy farms. Microb Pathog. 2017:104:278-86.

11. Reinoso EB, Lasagno MC, Dieser SA, Odierno LM. Distribution of virulenceassociated genes in Streptococcus uberis isolated from bovine mastitis. FEMS Microbiol Lett. 2011;318:183-8.

12. Carvalho-Castro GA, Silva JR, Paiva LV, Custódio DA, Moreira RO, Mian GF, et al. Molecular epidemiology of Streptococcus agalactiae isolated from mastitis in Brazilian dairy herds. Braz J Microbiol. 2017; https://doi.org/10.1016/j.bjm. 2017.02.004 
13. Ebrahimi A, Moatamedi A, Lotfalian S, Mirshokraei P. Biofilm formation, hemolysin production and antimicrobial susceptibilities of Streptococcus agalactiae isolated from the mastitis milk of dairy cows in Shahrekord district, Iran. Vet Res Forum. 2013:4:269-72.

14. Kaczorek E, Małaczewska J, Wójcik R, Rękawek W, Siwicki AK. Phenotypic and genotypic antimicrobial susceptibility pattern of Streptococcus spp. isolated from cases of clinical mastitis in dairy cattle in Poland. J Dairy Sci. 2017;100:6442-53.

15. Stepanović S, Vuković D, Hola V, Di Bonaventura G, Djukić S, Cirković I, Ruzicka F. Quantification of biofilm in microtiter plates: overview of testing conditions and practical recommendations for assessment of biofilm production by staphylococci. APMIS. 2007;115:891-9.

16. Poyart C, Tazi A, Réglier-Poupet H, Billoët A, Tavares N, Raymond J, et al. Multiplex PCR assay for rapid and accurate capsular typing of group B Streptococci. J Clin Microbiol. 2007:45:1985-8.

17. Abdelsalam M, Fujino M, Eissa AE, Chen SC, Warda M. Expression, genetic localization and phylogenic analysis of NAPIr in piscine Streptococcus dysgalactiae subspecies dysgalactiae isolates and their patterns of adherence. J Adv Res. 2015;6:747-55.

18. Calvinho LF, Almeida RA, Oliver SP. Potential virulence factors of Streptococcus dysgalactiae associated with bovine mastitis. Vet Microbiol. 1998;15:93-110.

19. Moliva MV, Cerioli F, Reinoso EB. Evaluation of environmental and nutritional factors and sua gene on in vitro biofilm formation of Streptococcus uberis isolates. Microb Pathog. 2017;107:144-8.

20. Shome BR, Bhuvana M, Mitra SD, Krithiga N, Shome R, Velu D, et al. Molecular characterization of Streptococcus agalactiae and Streptococcus uberis isolates from bovine milk. Trop Anim Health Prod. 2012; https://doi. org/10.1007/s11250-012-0167-4.

21. El-Behiry A, Elsayed M, Marzouk E, Bathich Y. Detection of virulence genes in Staphyococcus aureus and Streptococcus agalatctiae isolated from mastitis in the middle east. Br Microbiol Res J. 2015;10:1-9.

22. Jain B, Tewari A, Bhandari BB, Jhala MK. Antibiotic resistance and virulence genes in Streptococcus agalactiae isolated from cases of bovine subclinical mastitis. Vet Arhiv. 2012;82:423-32.

23. Yang Y, Liu Y, Ding Y, Yi L, Ma Z, Fan H, Lu C. Molecular characterization of Streptococcus agalactiae isolated from bovine mastitis in Eastern China. PLoS One. 2013; https://doi.org/10.1371/journal.pone.0067755.

24. Delannoy CM, Crumlish M, Fontaine MC, Pollock J, Foster G, Dagleish MP, et al. Human Streptococcus agalactiae strains in aquatic mammals and fish. BMC Microbiol. 2013;13:1471-80.

25. Dogan B, Schukken YH, Santisteban C, Boor KJ. Distribution of serotypes and antimicrobial resistance genes among Streptococcus agalactiae isolates from bovine and human hosts. J Clin Microbiol. 2005;43:5899-906.

26. Merl K, Abdulmawjood A, Lämmler C, Zschöck M. Determination of epidemiological relationships of Streptococcus agalactiae isolated from bovine mastitis. FEMS Microbiol Lett. 2003;12:87-92.

27. Richards VP, Lang P, Bitar PD, Lefébure T, Schukken YH, Zadoks RN, Stanhope MJ. Comparative genomics and the role of lateral gene transfer in the evolution of bovine adapted Streptococcus agalactiae. Infect Genet Evol. 2011;11:1263-75.

28. Perrig MS, Veaute C, Renna MS, Pujato N, Calvinho L, Marcipar I, et al. Assessment of the potential utility of different regions of Streptococcus uberis adhesion molecule (SUAM) for mastitis subunit vaccine development. Microb Pathog. 2017:105:273-9.

29. Luther DA, Almeida RA, Oliver SP. Elucidation of the DNA sequence of Streptococcus uberis adhesion molecule gene (sua) and detection of sua in strains of Streptococcus uberis isolated from geographically diverse locations. Vet Microbiol. 2008;128:304-12.

30. Yuan Y, Dego OK, Chen X, Abadin E, Chan S, Jory L, et al. Conservation of Streptococcus uberis adhesion molecule and the sua gene in strains of Streptococcus uberis isolated from geographically diverse areas. J Dairy Sci. 2014;97:7668-73

31. Ward PN, Leigh JA. Genetic analysis of Streptococcus uberis plasminogen activators. Indian J Med Res. 2004;119:136-40.

32. Perez-Casal J, Prysliak T, Potter AA. A GapC chimera retains the properties of the Streptococcus uberis wild-type GapC protein. Protein Expr Purif. 2004;33:288-96.

33. Field TR, Ward PN, Pedersen LH, Leigh JA. The hyaluronic acid capsule of Streptococcus uberis is not required for the development of infection and clinical mastitis. Infect Immun. 2003;71:132-9.
34. Wastfelt M, Stalhammar-Carlemalm M, Delisse AM, Cabezon T, Lindahl G. Identification of a family of streptococcal surface proteins with extremely repetitive structure. J Biol Chem. 1996;271:18892-7.

35. Jerlstrom PG, Chhatwal GS, Timmis KN. The IgA-binding beta antigen of the c protein complex of group B streptococci: sequence determination of its gene and detection of two binding regions. Mol Microbiol. 1991:5:843-9.

36. Bergseng $H$, Bevanger $L$, Rygg $M$, Bergh K. Real-time PCR targeting the sip gene for detection of group B Streptococcus colonization in pregnant women at delivery. J Med Microbiol. 2007;56:223-8.

37. Michel JL, Madoff LC, Olson K, Kling DE, Kasper DL, Ausubel FM. Large, identical, tandem repeating units in the $C$ protein alpha antigen gene, bca, of group B streptococci. Proc Natl Acad Sci U S A. 1992;89:10060-4.

38. Dimitriev A, Shakleina E, Tkàčikova L, Mikula I, Totolian A. Genetic heterogeneity of the pathogenic potentials of human and bovine group $B$ Streptococci. Folia Microbiol. 2002:47:291-5.

39. Pires R, Rolo D, Gama-Norton L, Morais A, Lito L, Salgado MJ, et al. Group A Streptococci from carriage and disease in Portugal: evolution of antimicrobial resistance and T antigenic types during 2000-2002. Microb Drug Resist. 2005;11:360-70.

\section{Submit your next manuscript to BioMed Central and we will help you at every step:}

- We accept pre-submission inquiries

- Our selector tool helps you to find the most relevant journal

- We provide round the clock customer support

- Convenient online submission

- Thorough peer review

- Inclusion in PubMed and all major indexing services

- Maximum visibility for your research

Submit your manuscript at www.biomedcentral.com/submit
) Biomed Central 